OPEN ACCESS

Edited by:

Leonard Peruski

Centers for Disease Control and

Prevention, USA

Reviewed by:

Jesús Santos,

Universidad de León, Spain

Christiane Gerke,

Institut Pasteur, France

Ruud H. Deurenberg,

University Medical Center Groningen

(UMCG), Netherlands

*Correspondence: Tracy Schmidt

tracy.schmidt@kzndard.gov.za

Specialty section

This article was submitted to

Infectious Diseases,

a section of the journal

Frontiers in Microbiology

Received: 03 January 2017

Accepted: 13 March 2017

Published: 06 April 2017

Citation:

Schmidt T, Kock MM and Ehlers MM (2017) Molecular Characterization of Staphylococcus aureus Isolated from Bovine Mastitis and Close Human

Contacts in South African Dairy

Herds: Genetic Diversity and Inter-Species Host Transmission.

Front. Microbiol. 8:511

doi: 10.3389/fmicb.2017.00511

\section{Molecular Characterization of Staphylococcus aureus Isolated from Bovine Mastitis and Close Human Contacts in South African Dairy Herds: Genetic Diversity and Inter-Species Host Transmission}

\author{
Tracy Schmidt ${ }^{1,2 *}$, Marleen M. Kock ${ }^{2,3}$ and Marthie M. Ehlers ${ }^{2,3}$
}

\begin{abstract}
${ }^{1}$ Allerton Provincial Veterinary Laboratory, KwaZulu-Natal Department of Agriculture and Rural Development, Pietermaritzburg, South Africa, ${ }^{2}$ Department of Medical Microbiology, University of Pretoria, Pretoria, South Africa, ${ }^{3}$ Tshwane Academic Division, National Health Laboratory Service, Pretoria, South Africa
\end{abstract}

Staphylococcus aureus is one of the most common etiological agents of contagious bovine mastitis worldwide. The purpose of this study was to genetically characterize a collection of $S$. aureus isolates (bovine $=146$, human $=12$ ) recovered from cases of bovine mastitis and nasal swabs of close human contacts in the dairy environment. Isolates were screened for a combination of clinically significant antimicrobial and virulence gene markers whilst the molecular epidemiology of these isolates and possible inter-species host transmission was investigated using a combination of genotyping techniques. None of the isolates under evaluation tested positive for methicillin or vancomycin resistance encoding genes. Twenty seven percent of the bovine S. aureus isolates tested positive for one or more of the pyrogenic toxin superantigen (PTSAg) genes with the $\mathrm{sec}$ and sell genes predominating. Comparatively, 83\% of the human S. aureus isolates tested positive for one or more PTSAg genes with a greater variety of genes being detected. Genomic DNA macrorestriction followed by pulsed-field gel electrophoresis (PFGE) of the bovine isolates generated 58 electrophoretic patterns which grouped into 10 pulsotypes at an $80 \%$ similarity level. The majority of the bovine isolates, 93.2\% (136/146), clustered into four major pulsotypes. Seven sequence types (ST) were identified among the representative bovine $S$. aureus isolates genotyped, including: ST8 (CC8), ST97 (CC97), ST351 (CC705), ST352 (CC97), ST508 (CC45), ST2992 (CC97) and a novel sequence type, ST3538 (CC97). Based on PFGE analysis, greater genetic diversity was observed among the human $S$. aureus isolates. Bovine and human isolates from three sampling sites clustered together and were genotypically indistinguishable. Two of the isolates, ST97 and ST352 belong to the common bovine lineage CC97, and their isolation from close human contacts suggests zoonotic transfer. In the context of this study, the third isolate, ST8 (CC8), is believed to be a human 
clone which has transferred to a dairy cow and has subsequently caused mastitis. The detection of indistinguishable $S$. aureus isolates from bovine and human hosts at three of the sampling sites is suggestive of bacterial transmission and supports the need for vigilant monitoring of staphylococcal populations at the human-animal interface.

Keywords: Staphylococcus aureus, bovine mastitis, PFGE, MLST, inter-species transmission

\section{INTRODUCTION}

Staphylococcus aureus is a versatile pathogen responsible for a variety of infections in humans and animals (Hata et al., 2008). In humans $S$. aureus is responsible for a number of conditions ranging from superficial skin infections to life-threatening diseases, such as endocarditis and hemolytic pneumonia (Lindsay and Holden, 2004). Additionally, through the production of toxins, $S$. aureus can cause specific toxin-mediated conditions, such as scalded skin syndrome, staphylococcal food poisoning and toxic shock syndrome (Becker et al., 2015). In animals, S. aureus is a common etiological agent of mastitis, an infectious disease condition responsible for significant financial losses to dairy farmers worldwide (Petrovski et al., 2006; Fitzgerald, 2012).

The success of $S$. aureus as a pathogen is attributable, in part, to the diverse range of virulence factors produced (Gordon and Lowy, 2008). The virulence factors facilitate the invasion and colonization of host tissue, evasion of the hosts' immune defence mechanisms, aid in acquisition of nutrients and dissemination of the bacteria within the host tissue (Ferry et al., 2005; Haveri et al., 2008). Among the vast array of virulence factors produced are numerous enzymes and cytotoxins, such as coagulase, collagenase, exfoliative toxins, hemolysins, hyaluronidase, leukocidins, lipases, nucleases and staphylokinase (Smeltzer et al., 2009). Most S. aureus strains are able to produce one or more pyrogenic toxin superantigens (PTSAgs) which includes staphylococcal enterotoxins and the structurally related protein, toxic shock syndrome toxin-1 (TSST1) (Wright and Novick, 2003). All of these toxins exhibit superantigenic activity by interacting with antigen-presenting cells and T-lymphocytes irrespective of the antigen specificity of the cells (Akineden et al., 2001; Argudín et al., 2010). This interaction leads to a massive proliferation of T-cells and the uncontrolled release of pro-inflammatory cytokines that can lead to clinical signs in the host that include, fever, hypotension and shock (Plata et al., 2009; Argudín et al., 2010). The production of enterotoxins is particularly significant from a public health standpoint as the ingestion of preformed toxins is a major cause of food poisoning worldwide (Le Loir et al., 2003; Srinivasan et al., 2006). The expression of most staphylococcal virulence factors occurs in a co-ordinated manner and is strictly controlled by a series of regulatory genes which operate under the control of the accessory gene regulator (agr) (Ben Ayed et al., 2008; Lowy, 2013).

Staphylococcus aureus is a contagious mastitis pathogen with the milk from infected mammary glands serving as the primary reservoir of the bacterium which may be transferred to other animals in the herd during milking (Capurro et al., 2010). Several epidemiological studies have suggested that a few specialized $S$. aureus strains are responsible for the majority of bovine intramammary infections (IMIs) worldwide (Kapur et al., 1995; Zadoks et al., 2002; Sakwinska et al., 2011; Budd et al., 2015). However, the occurrence of herd-specific strains has also been reported (Joo et al., 2001; Sommerhäuser et al., 2003; Rabello et al., 2007; Oliveira et al., 2011). Moreover, it has been demonstrated that different strains are associated with different clinical outcomes in the host including severity and persistence of infections and response to antimicrobial treatment (Haveri et al., 2005, 2007; Lundberg et al., 2014). A better understanding of the epidemiology, including transmission and virulence characteristics of $S$. aureus strains may assist with the development of strategies to control the spread of the bacterium within herds (Haveri et al., 2005, 2008).

In the dairy environment documented evidence of methicillin-resistant $S$. aureus transmission between cows and close human contacts exists (Juhász-Kaszanyitzky et al., 2007; Haenni et al., 2010). Further, reports of livestockassociated MRSA (LA-MRSA) ST398 causing mastitis have created additional public health concerns regarding production animals, including dairy cows, as a source of antimicrobialresistant bacteria which can spill-over into humans (Monecke et al., 2007; Feßler et al., 2010; Fitzgerald, 2012; Tenhagen et al., 2014). It is now commonly accepted that persons working in close contact with animals are at a higher risk of being colonized or even infected with zoonotic bacteria carried by animals than individuals who do not interact with animals (Graveland et al., 2011). It is therefore recommended that surveillance at the interface between human and animal hosts is monitored in order to detect any potential, emerging human health risks (Fitzgerald, 2012; Cuny et al., 2015).

A number of genotyping methods have been used to characterize $S$. aureus isolates including virulence gene profiling, agr typing, pulsed-field gel electrophoresis (PFGE), spa sequence typing and multilocus sequence typing (MLST) (Hata et al., 2010; Kadlec et al., 2015). The application of whole genome sequencing (WGS) has gained traction during the past decade as technological advances have improved the accessibility and cost-effectiveness of high-throughput sequencing (Trees et al., 2015). At present however, WGS still remains unaffordable in resource-limited settings.

In a previous study our group investigated the diversity and antimicrobial susceptibility of staphylococci responsible for causing bovine IMIs (Schmidt et al., 2015). Concurrent sampling and characterization of staphylococci from close contact workers facilitated a comparison between isolates from different hosts. To date no genotyping studies have been undertaken in South Africa to investigate the genetic diversity of $S$. aureus strains causing IMIs and the potential public health risk posed by these 
bacterial populations. Using our previous work as a platform the purpose of the present study was to (i) screen isolates for clinically significant antimicrobial and virulence gene markers including: antimicrobial resistance (blaZ, mecA, mec $\mathrm{C}$, van $\mathrm{A}$, $v a n \mathrm{~B})$, exfoliative toxin (eta, etb, etd), hemolysin ( $h l a, h l b$, $h l d, h l g, h l g 2)$, leukocidin (lukED, lukM, lukS/F) and pyrogenic superantigen toxins (sea to see, seg to sei, selj to selr, selu and tst) among bovine and human $S$. aureus isolates; (ii) investigate the diversity of $S$. aureus genotypes causing mastitis in dairy herds through genomic macrorestriction and PFGE analysis of isolates; (iii) relate the occurrence of local genotypes to global $S$. aureus lineages, and (iv) evaluate the genetic relatedness of $S$. aureus isolates causing mastitis and isolates recovered from humans working in close contact with the animals.

\section{MATERIALS AND METHODS}

\section{Ethics Statement}

Ethical clearance for this investigation was obtained from the Animal Ethics Committee (Faculty of Veterinary Science, H01013) and the Research Ethics Committee (Faculty of Health Sciences, 295/2013) of the University of Pretoria. Participation in this study was voluntary and written informed consent was obtained from all animal owners and human contacts prior to sampling.

\section{Bacterial Isolates}

A total of $146 \mathrm{~S}$. aureus isolates from milk and 12 isolates from human nasal swabs were characterized in this study. The samples originated from 13 sampling sites (identified by letters A to J and $\mathrm{L}$ to $\mathrm{M}$ ) located in the province of KwaZulu-Natal (KZN), South Africa (Figure 1). At the time of sampling animal owners were asked to provide details regarding the: average size of their dairy herd; intramammary preparations used; number of laborers working in the dairy; and the source of new heifers.

Sample collection, processing and bacteriological analyses are described in detail elsewhere (Schmidt et al., 2015). All Staphylococcus aureus isolates were identified by means of standard phenotyping methods including coagulase production using rabbit plasma (Bio-Rad, USA) and the detection of clumping factor, fibronectin-binding proteins and protein A using the Pastorex ${ }^{\mathrm{TM}}$ StaphPlus latex agglutination test kit (BioRad, USA). Phenotypic results were confirmed using a multiplex-PCR (M-PCR) assay (Schmidt et al., 2015).

\section{Detection of Virulence Factors and Immune Evasion Cluster Genes}

The genomic DNA of all test isolates was extracted using the DNeasy blood and tissue kit (Qiagen, Germany) in accordance with the manufacturer's instructions. Isolates were evaluated using nine M-PCR assays (AMR1, VGP1 to VGP8) to screen

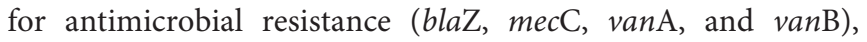
exfoliative (eta, etb, etd), hemolysin ( $h l a, h l b, h l d, h l g, h l g 2)$, leukocidin (lukM, lukED) and PTSAg (sea to see, seg to sei, selj to selr, seu, tst) genes. Multiplex PCR assays were carried out using the Qiagen Multiplex PCR kit (Germany) according to the manufacturer's instructions. The presence of the human immune

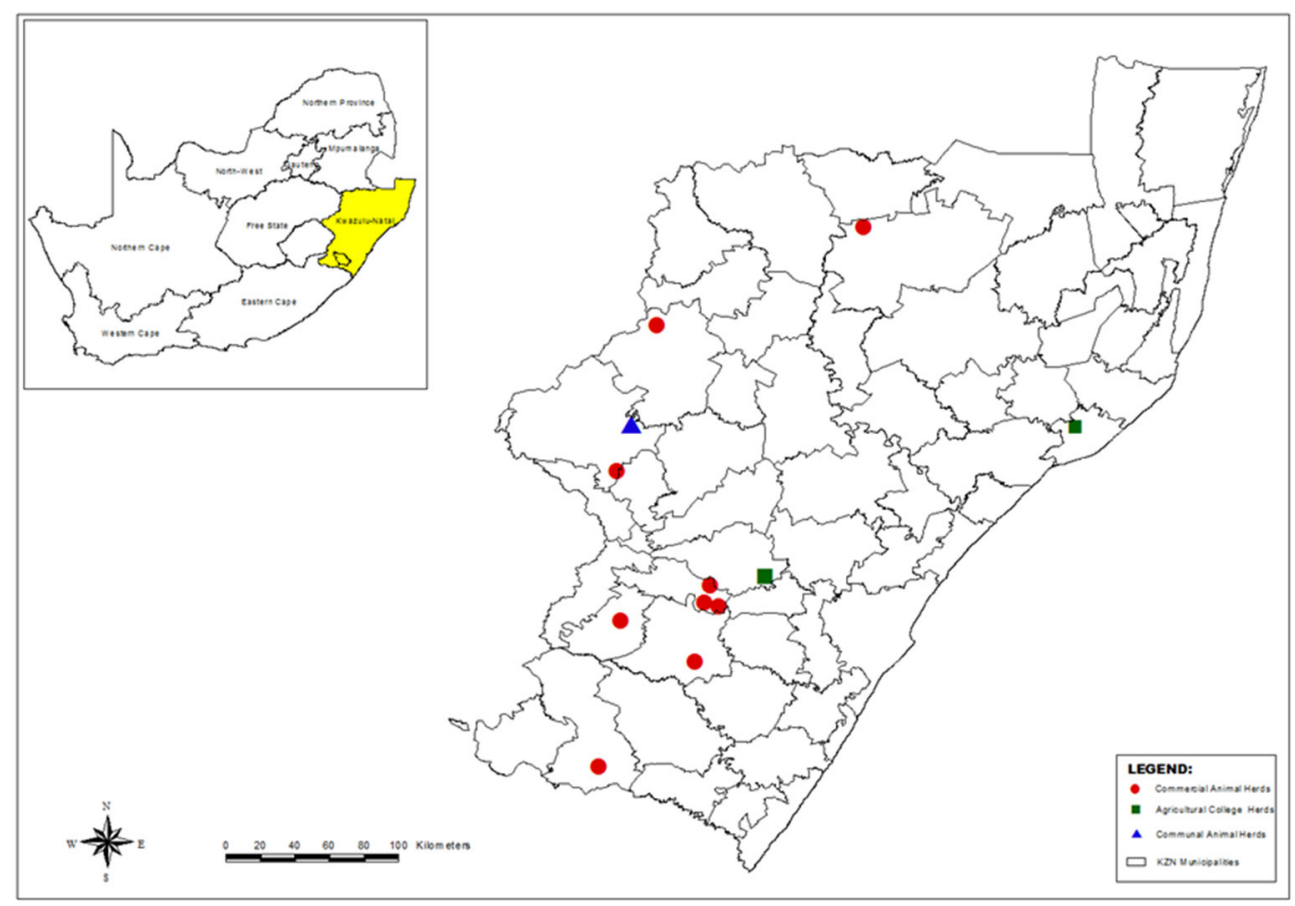

FIGURE 1 | Map of KwaZulu-Natal, South Africa, showing the municipal districts and the location of the dairy herds where sampling was carried out (Generated using ArcMap version 10). 
evasion cluster (IEC) genes, $c h p$, sak and $s c n$ were assayed using separate uniplex PCR assays. Two microliters of each DNA extract was added to $\mathrm{PCR}$ reaction mixtures comprising of $1 \mathrm{X}$ PCR buffer (Promega, USA), $1.5 \mathrm{mM} \mathrm{MgCl}$ (Promega, USA), $0.4 \mathrm{mM}$ dNTPs (Promega, USA), $0.5 \mu \mathrm{M}$ of each primer and 2.5 IU HotStart Taq (Promega, USA).

Details of all the oligonucleotide primers, PCR assay conditions and positive control isolates used are summarized in Table 1. All PCR reactions were cycled in a MJ Mini thermocycler (BioRad, USA) with appropriate positive (Table 1) and negative (deionized water) controls. Amplification products were electrophoresed in a $1.8 \%(\mathrm{~m} / \mathrm{v})$ agarose gel (SeaKem, Lonza, USA) in a $1 \mathrm{X}$ Tris-borate-EDTA (TBE) buffer (Melford, UK). Following staining in a $1 \mu \mathrm{g} / \mathrm{mL}$ ethidium bromide solution $(10 \mathrm{mg} / \mathrm{mL})$ (BioRad, USA) the PCR products were visualized and documented (UVIPro, Uvitec, UK). A 100 bp molecular weight marker (MWM) (Solis BioDyne, Estonia or Thermo Scientific, USA) was electrophoresed alongside samples to enable the size of the PCR products to be determined.

\section{Accessory Gene Regulator (agr) typing}

The agr allele types (I-IV) of all S. aureus isolates were determined as described by Gilot et al. (2002). The multiplex-PCR assay comprised of a forward primer, Pan, common to all agr groups and four reverse primers each one specific to each agr group (Gilot et al., 2002). Amplification products were electrophoresed as described in Section Detection of Virulence Factors and Immune Evasion Cluster Genes.

\section{Genomic Macrorestriction and Pulsed-Field Gel Electrophoresis of Staphylococcus aureus Isolates}

All S. aureus isolates were characterized by macrorestriction of genomic DNA using SmaI followed by PFGE of the restriction products. The procedure followed is based on protocols described by Graves and Swaminathan (2001) and McDougal et al. (2003) but with several modifications. Staphylococcus aureus ATCC 12600 was processed and electrophoresed together with each batch of test samples. Bacterial cell suspensions were prepared in TE buffer (10 mM Tris-HCL, 1 mM EDTA, pH 8.0, SigmaAldrich, USA) and the turbidity adjusted to 1.2-1.6 using a microplate reader at $630 \mathrm{~nm}$ (ELx 800, BioTEK, USA). Twenty microliters of lysozyme $(20 \mathrm{mg} / \mathrm{mL}$; Sigma-Aldrich, USA) was added to $400 \mu \mathrm{L}$ of each cell suspension and incubated (LabNet International Inc., USA) at $56^{\circ} \mathrm{C}$ for $20 \mathrm{~min}$. Following incubation, $20 \mu \mathrm{L}$ proteinase $\mathrm{K}(20 \mathrm{mg} / \mathrm{mL}$; Roche, Germany) and $5 \mu \mathrm{L}$ lysostaphin ( $1 \mathrm{mg} / \mathrm{mL}$; Sigma-Aldrich, USA) was added to each sample before an equal volume of molten $1.2 \%(\mathrm{~m} / \mathrm{v})$ SeaKem ${ }^{\circledR}$ LE agarose (Lonza, USA) was added. Each sample suspension was gently mixed before being transferred to a reusable plug mold (Biometra, Germany) and allowed to solidify. Sample plugs were transferred to separate $15 \mathrm{~mL}$ conical tubes (Falcon, México) containing $5 \mathrm{~mL}$ cell lysis buffer $(50 \mathrm{mM}$ Tris$\mathrm{HCl} \mathrm{pH}$ 8.0, 50 mM EDTA, pH 8.0, 1\% sodium lauryl sarcosine, Sigma-Aldrich, USA) and $25 \mu \mathrm{L}$ proteinase $\mathrm{K}(20 \mathrm{mg} / \mathrm{mL})$ (Roche, Germany). Sample tubes were incubated (Stuart ${ }^{\circledR}$, Bibby
Scientific Ltd., UK) for $18-24 \mathrm{~h}$ at $51^{\circ} \mathrm{C}$ with constant agitation at $170 \mathrm{rpm}$. Following incubation the plugs were washed as described by Graves and Swaminathan (2001). Appropriately sized slices were cut from each plug and digested with $50 \mathrm{IU}$ SmaI (New England BioLabs, USA) at $37^{\circ} \mathrm{C}$ for $2 \mathrm{~h}$. Plug slices were sealed in the wells of a $1.2 \%(\mathrm{~m} / \mathrm{v})$ SeaKem ${ }^{\circledR}$ LE agarose gel (Lonza, USA) and electrophoresed in $0.25 \mathrm{X} \mathrm{TBE}$ buffer ( $\mathrm{pH} 8.3$; Sigma-Aldrich, USA) using the Rotaphor ${ }^{\circledR}$ system (Biometra, Germany). The electrophoretic parameters were set as follows: switch times of 5-40 s; angle $120^{\circ}$ constant; $220 \mathrm{~V}$ linear to $200 \mathrm{~V}$ for $25 \mathrm{~h}$ at $13^{\circ} \mathrm{C}$. Following electrophoresis the gel was stained in a $0.25 \mu \mathrm{g} / \mathrm{mL}$ ethidium bromide solution $(10 \mathrm{mg} / \mathrm{mL}$; Sigma-Aldrich, USA) for $15 \mathrm{~min}$ and de-stained in deionized water for $30 \mathrm{~min}$. Gels were visualized and captured using a gel documentation system (UVPro, Uvitec, UK). All gel images were analyzed using the GelCompar II software program (Applied Maths, Belgium). Similarity co-efficients were calculated and a dendrogram constructed using the Dice coefficient and UPGMA. A band position tolerance of $1.0 \%$ was used and the cluster (pulsotype, PT) cut-off was set at an $80 \%$ similarity level which corresponds to the Tenover et al. (1995) criteria of four to six band differences between related isolates (McDougal et al., 2003; Faria et al., 2008). All pulsotypes were assigned Arabic numerals and were classified as being either major pulsotypes ( $\geq 5$ isolates), minor pulsotypes (two to three isolates) or singletons. Sixteen bovine isolates, representative of all pulsotypes, and 10 isolates of human origin were genotyped further using sequence analysis of the spa gene and MLST.

\section{Sequence Typing of the Staphylococcal Protein A Gene of Staphylococcus aureus Isolates}

The polymorphic X-Region of the spa gene was amplified according to the protocol of Harmsen et al. (2003) and the PCR amplicons were submitted to Inqaba Biotechnical Industries (South Africa) for sequencing. Sequence files were assembled using CLC Main Workbench Version 6.0 (CLCbio, USA) before being imported and analyzed in DNAgear (201203012225). Novel repeat sequence profiles and trace data files were submitted to the Ridom Spa server database curator for evaluation and assignment of new spa types.

\section{Multilocus Sequence Typing Analysis of Staphylococcus aureus Isolates}

The internal fragments of seven $S$. aureus housekeeping genes (arcC, $\operatorname{aro\mathrm {E}}, g l p \mathrm{~F}, g m k, p t a$, $t p i$, and $y q i \mathrm{~L}$ ) were amplified as previously described (Enright et al., 2000). The PCR amplicons were submitted to Inqaba Biotechnical Industries (South Africa) for DNA sequencing of both the forward and reverse strands. Following assembly of the DNA sequences in CLC Main Workbench version 6.0 (CLCbio, USA) the sequence of each locus was compared to allele sequences in the MLST database (http://saureus.mlst.net). The combination of alleles at the seven loci was used to define the allelic profile for each isolate and assigned to a sequence type (ST). The eBURST algorithm (version 3.0; last previous update 24/9/2015) was used to assign MLST 
TABLE 1 | Oligonucleotide primer sequences and details for the PCR-based assays used in this study to characterize S.aureus.

\begin{tabular}{|c|c|c|c|c|c|}
\hline Gene & Primer name & Oligonucleotide sequence $\left(5^{\prime}-3^{\prime}\right)^{\dagger}$ & $\begin{array}{l}\text { Size of PCR } \\
\text { amplicon (bp) }\end{array}$ & Positive control & References \\
\hline $16 \mathrm{~S}$ rRNA* & Staph 756F & AACTCTGTTATTAGGGAAGAACA & 756 & None & McClure et al., 2006 \\
\hline \multicolumn{6}{|l|}{ AMR1 $^{\mathrm{a}}$} \\
\hline blaz & blaZ-F & AAGAGATTTGCCTATGCTTC & 517 & S. aureus & $\begin{array}{l}\text { Vesterholm-Nielsen } \\
\text { et al., } 1999\end{array}$ \\
\hline \multirow[t]{2}{*}{$\operatorname{mecC}$} & $\begin{array}{l}\text { mecA } A_{L G A 251} \\
\text { MultiFP }\end{array}$ & GAAAAAAAGGCTTAGAACGCCTC & 138 & S. aureus field isolate 13ANR24389_RV & Stegger et al., 2012 \\
\hline & $\begin{array}{l}\text { mecA } A_{L G A 251} \\
\text { MultiRP }\end{array}$ & GAAGATCTITCCGTITCAGC & & & \\
\hline \multirow[t]{2}{*}{$\operatorname{vanA}$} & $\operatorname{vanA-F}$ & CATGAATAGAATAAAAGTTGCAATA & 1,030 & Enterococcus faecalis & Clark et al., 1993 \\
\hline & $\operatorname{vanA-R}$ & CСCCПTTAACGCTAATACGATCAA & & ATCC 70021 & \\
\hline \multirow[t]{2}{*}{ sea } & GSEAR-1 & GGTTATCAATGTGCGGGTGG & 102 & S. aureus field isolate 00V08510 & Mehrotra et al., 2000 \\
\hline & GSEAR-2 & CGGCACTIIITCTCTTCGG & & & \\
\hline \multirow[t]{2}{*}{ seb } & GSEBR-1 & GTATGGTGGTGTAACTGAGC & 164 & S. aureus field isolate 00V08510 & \\
\hline & GSEBR-2 & CCAAATAGTGACGAGTTAGG & & & \\
\hline \multirow[t]{2}{*}{$\sec$} & GSECR-1 & AGATGAAGTAGTTGATGTGTATGG & 451 & S. aureus field isolate & \\
\hline & GSECR-2 & CACACTITAGAATCAACCG & & 13ANR24389_RV & \\
\hline \multirow[t]{2}{*}{ sed } & GSEDR-1 & CCAATAATAGGAGAAAATAAAAG & 278 & S. aureus field isolate & \\
\hline & GSEDR-2 & ATTGGTATIIIIITCGTTC & & 13ANR12816 & \\
\hline \multirow[t]{2}{*}{ see } & GSEER-1 & AGGTIITTCACAGGTCATCC & 209 & S. aureus field isolate & \\
\hline & GSEER-2 & CTIIIITCTTCGGTCAATC & & Jena_FLI W56 & \\
\hline \multicolumn{6}{|l|}{ VGP2 $^{a}$} \\
\hline \multirow[t]{2}{*}{ selj } & SEJ-1 & ATAGCATCAGAACTGTTGTTCCG & 152 & S. aureus field isolate & \\
\hline & SEJ-2 & СТTCTGAATTTACCACCAAAGG & & 13ANR12816 & \\
\hline \multirow[t]{2}{*}{ selp } & SEP-3 & TGATTATTAGTAGACCTTGG & 396 & S. aureus field isolate & \\
\hline & SEP-4 & ATAACCAACCGAATCACCAG & & 13ANR12816 & \\
\hline \multicolumn{6}{|l|}{ VGP3 $^{a}$} \\
\hline \multirow[t]{2}{*}{ selk } & SEK-1 & TAGGTGTCTCTAATAATGCCA & 293 & S. aureus field isolate 00V08510 & Omoe et al., 2005 \\
\hline & SEK-2 & TAGATATTCGTTAGTAGCTG & & & \\
\hline \multirow[t]{2}{*}{ selm } & SEM-1 & GGATAATTCGACAGTAACAG & 379 & S. aureus field isolate & \\
\hline & SEM-2 & TCCTGCATTAAATCCAGAAC & & 13ANR12816 & \\
\hline \multirow[t]{2}{*}{ selo } & SEO-1 & TGTGTAAGAAGTCAAGTGTAG & 214 & S. aureus field isolate & \\
\hline & SEO-2 & TCTIAGAAATCGCTGATGA & & 13ANR12816 & \\
\hline tst1 & GTSSTR-1 & АССССТGTTСССТTATCATC & 326 & S. aureus field isolate & Mehrotra et al., 2000 \\
\hline & GTSSTR-2 & TITCAGTATTTGTAACGCC & & 05-Student-18 & \\
\hline VGP4 ${ }^{a}$ & & & & & \\
\hline sell & SEL-1 & TAACGGCGATGTAGGTCCAGG & 383 & S. aureus field isolate & Omoe et al., 2005 \\
\hline & SEL-2 & CATCTATTTCTTGTGCGGTAAC & & 07V33069 & \\
\hline selq & SEQ-1 & AATCTCTGGGTCAATGGTAAGC & 122 & S. aureus field isolate 00V08510 & \\
\hline & SEQ-2 & TTGTATTCGTITGTAGGTATITCG & & & \\
\hline
\end{tabular}




\section{TABLE 1 | Continued}

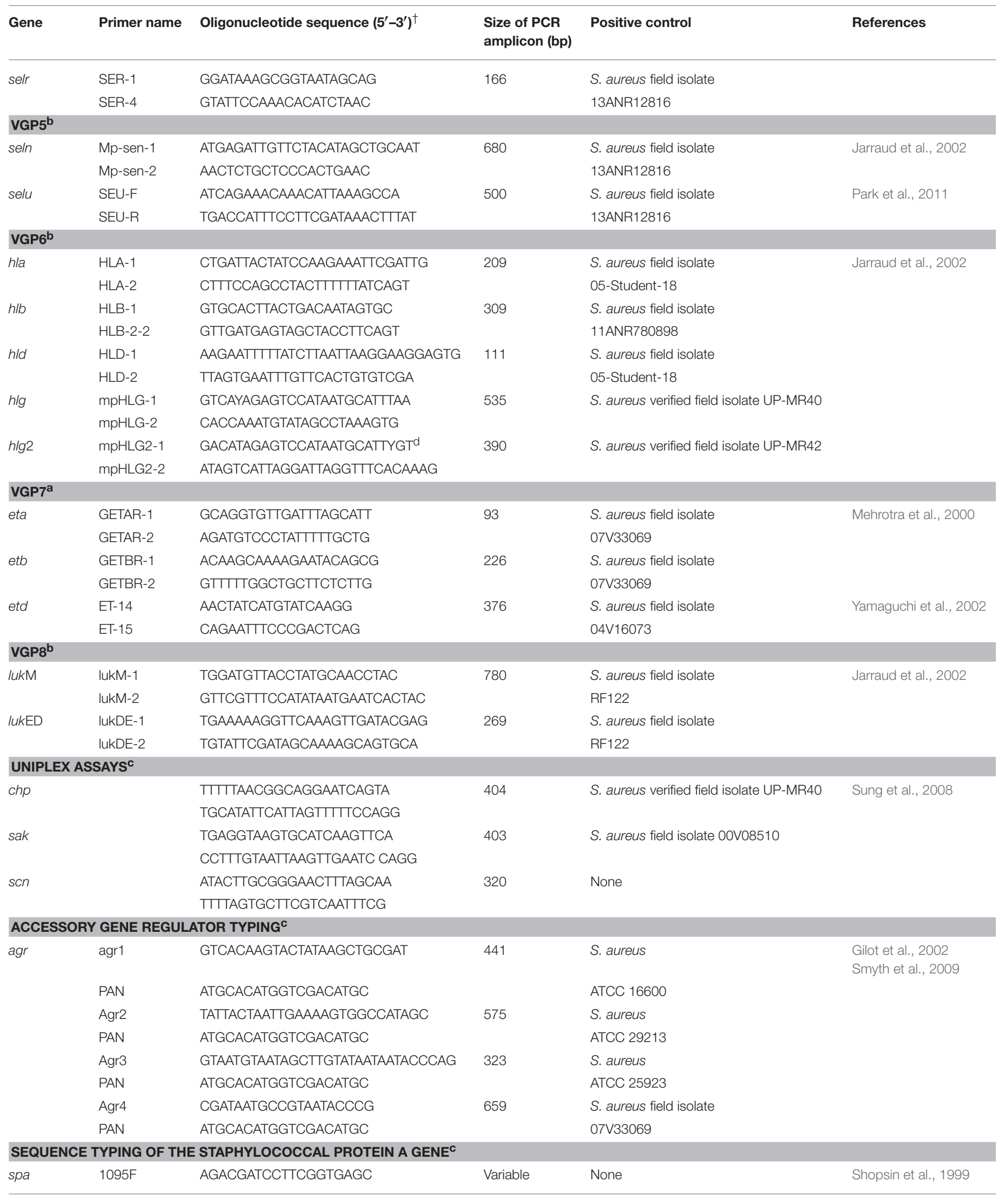




\section{TABLE 1 | Continued}

\begin{tabular}{|c|c|c|c|c|c|}
\hline Gene & Primer name & Oligonucleotide sequence $\left(5^{\prime}-3^{\prime}\right)^{\dagger}$ & $\begin{array}{l}\text { Size of PCR } \\
\text { amplicon (bp) }\end{array}$ & Positive control & References \\
\hline & 1517R & GCTITGCAATGTCATTACTG & & & Harmsen et al., 2003 \\
\hline \multicolumn{6}{|c|}{ MULTILOCUS SEQUENCE TYPINGC } \\
\hline \multirow[t]{2}{*}{$\operatorname{arcC}$} & $\operatorname{arc}-U p$ & TTGATTCACCAGCGCGTATTGTC & 456 & None & Enright et al., 2000 \\
\hline & arc-Dn & AGGTATCTGCTTCAATCAGCG & & & \\
\hline \multirow[t]{2}{*}{ aroE } & aroE-Up & ATCGGAAATCCTATTTCACATTC & 456 & None & \\
\hline & aroE-Dn & GGTGTTGTATTAATAACGATATC & & & \\
\hline \multirow[t]{2}{*}{$g / p F$} & glpF-Up & CTAGGAACTGCAATCTTAATCC & 465 & None & \\
\hline & g/pF-Dn & TGGTAAAATCGCATGTCCAATTC & & & \\
\hline \multirow[t]{2}{*}{ gmk } & gmk-Up & ATCGTITATCGGGACCATC & 429 & None & \\
\hline & gmk-Dn & TCATTAACTACAACGTAATCGTA & & & \\
\hline \multirow[t]{2}{*}{ pta } & pta-Up & GTTAAAATCGTATTACCTGAAGG & 474 & None & \\
\hline & pta-Dn & GACCCTITGTTGAAAAGCTTAA & & & \\
\hline \multirow[t]{2}{*}{ tpi } & tpi-Up & TCGTTCATTCTGAACGTCGTGAA & 402 & None & \\
\hline & tpi-Dn & TITGCACCTTCTAACAATTGTAC & & & \\
\hline \multirow[t]{2}{*}{ yqiL } & yqiL-Up & CAGCATACAGGACACCTATTGGC & 516 & None & \\
\hline & yqiL-Dn & CGTTGAGGAATCGATACTGGAAC & & & \\
\hline
\end{tabular}

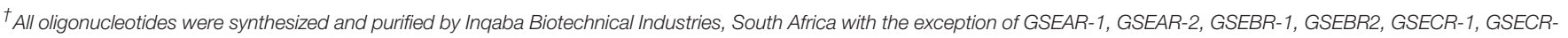

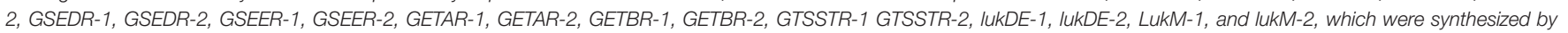
Integrated DNA Technologies (IDT $\left.{ }^{\circledR}\right)$ (California, USA).

*The $16 S$ primer pair was included in the following M-PCR assays: AMR1, VGP1, VGP2, VGP3, VGP4, VGP 6, and VGP7.

a Annealing temperature $57^{\circ} \mathrm{C}$.

${ }^{b}$ Annealing temperature $51^{\circ} \mathrm{C}$

${ }^{c}$ Annealing temperature $55^{\circ} \mathrm{C}$.

${ }^{d} Y=T$ or $C$.

clonal complexes, with the minimum number of common alleles set at six of seven (Feil et al., 2003). Trace files of putative novel alleles and the allelic profiles of novel STs were submitted to the curator of the database for evaluation, assignment of allele or ST number and entry into the database.

\section{RESULTS}

The distribution of samples and $S$. aureus isolates recovered at each of the sampling sites is summarized in Table 2. For further details pertaining to sampling and selection of bacterial isolates the reader is referred to Schmidt et al. (2015).

\section{Phenotypic and Molecular Identification of Staphylococcus aureus Isolates}

All $S$. aureus isolates tested positive for coagulase production using rabbit plasma. With the exception of 10 isolates from sampling site F, all $S$. aureus isolates tested positive with the Pastore $^{\text {TM }}$ StaphPlus agglutination test kit. The phenotypic identification of $S$. aureus isolates was confirmed using the species-specific multiplex-PCR assay.

\section{Virulence Gene Profiling of Staphylococcus aureus Isolates}

The distribution of virulence genes between the different $S$. aureus pulsotypes is shown in Table 3. None of the bovine or human $S$. aureus isolates tested positive for the presence of either of the methicillin resistance genes, mecA or mecC, or the vancomycin resistance genes, van $\mathrm{A}$ or $\operatorname{van\mathrm {B}}$. The blaZ gene was detected in $28.8 \%(42 / 146)$ and $75 \%(8 / 12)$ of the bovine and human $S$. aureus isolates respectively. All $S$. aureus isolates tested positive for the hemolysin genes, hla and hld. The hlg and hlg2 genes were detected in all the bovine isolates and 75\% (9/12) and $67 \%(8 / 12)$ of the human isolates respectively. The $\beta$-hemolysin gene was detected in $86 \%(126 / 146)$ of the bovine isolates and only $25 \%(3 / 12)$ of the human isolates. None of the $S$. aureus isolates tested positive for the Panton-Valentine leukocidin toxin gene, lukS/F. All bovine $S$. aureus isolates tested positive for lukED whilst this leukocidin gene was found in only $75 \%(8 / 12)$ of the isolates of human origin. Comparatively, the lukM gene was detected in $56.2 \%(82 / 146)$ of the bovine isolates and only a single human isolate. None of the bovine isolates tested positive for the exfoliative toxin genes eta, etb, or etd. Only a single human $S$. aureus isolate tested positive for the eta gene.

Overall 27\% (39/146) of the bovine S. aureus isolates and $83.3 \%(10 / 12)$ of the $S$. aureus isolates of human origin tested positive for one or more PTSAg genes. The PTSAg gene positive bovine $S$. aureus were isolated from only three of the sampling sites namely, commercial dairy herds E, F and L. The sec and sell genes were the most common genes detected among the bovine isolates with the sec-sell gene combination occurring in $71.8 \%$ (28/39) of the PTSAg-positive S. aureus isolates. Comparatively, a more diverse range of PTSAg toxin genes were detected among the human isolates including: sea $(n=1), \sec (n=3)$, sed $(n$ $=1)$, seg $(n=5)$, sei $(n=3)$, selj $(n=3)$, selk $(n=1)$, sell $(n=3), \operatorname{selm}(n=3)$, seln $(n=2)$, selo $(n=3)$, selq $(n=$ 
TABLE 2 | Distribution of Staphylococcus aureus isolates and pulsotypes from bovine intramammary infections and human nasal swabs collected from 13 sampling sites in the province of KwaZulu-Natal, South Africa.

\begin{tabular}{|c|c|c|c|c|c|}
\hline \multirow{2}{*}{$\begin{array}{l}\text { Sampling } \\
\text { sites }\end{array}$} & \multirow{2}{*}{$\begin{array}{l}\text { Average size of } \\
\text { milking herd }\end{array}$} & \multicolumn{2}{|c|}{ Bovine milk samples } & \multicolumn{2}{|c|}{ Human nasal swab specimens } \\
\hline & & $\begin{array}{l}\text { Percentage of sampled cows } \\
\text { positive for S.aureus }\end{array}$ & $\begin{array}{l}\text { Pulsotypes* (number of } \\
\text { isolates) }\end{array}$ & $\begin{array}{l}\text { Percentage of specimens } \\
\text { positive for S.aureus }\end{array}$ & $\begin{array}{l}\text { Pulsotypes* (number of } \\
\text { isolates) }\end{array}$ \\
\hline \multicolumn{6}{|c|}{ COMMERCIAL DAIRY HERDS $(n=9)$} \\
\hline A & 400 & $5.6(5 / 89)$ & PT7 (5) & $12.5(1 / 8)$ & PT14 (1) \\
\hline$B$ & 700 & $25.9(14 / 54)$ & PT7 (12), PT8 (2) & $25(2 / 8)$ & PT17 (2) \\
\hline C & 300 & $4.8(3 / 63)$ & PT7 (3) & $7.1(1 / 14)$ & PT12 (1) \\
\hline$E$ & 1,100 & $10.5(29 / 277)$ & PT2 (29) & $12.5(1 / 8)$ & PT2 (1) \\
\hline $\mathrm{F}$ & 500 & $18.3(22 / 120)$ & PT7 (12), PT10 (10) & $14.3(1 / 7)$ & PT13 (1) \\
\hline G & 95 & $14.5(18 / 124)$ & $\begin{array}{c}\text { PT1 (9), PT2 (7), PT7 (1), } \\
\text { PT8 (1) }\end{array}$ & $0(0 / 4)$ & - \\
\hline । & 500 & $21.4(21 / 98)$ & $\begin{array}{c}\text { PT1 (12), PT3 (1), PT4 (3), } \\
\text { PT6 (1), PT7 (4) }\end{array}$ & $0(0 / 6)$ & - \\
\hline J & 600 & $0(0 / 281)$ & - & $27.3(3 / 11)$ & PT11 (2), PT15 (1) \\
\hline $\mathrm{L}$ & 1,450 & $7.8(16 / 206)$ & PT5 (1), PT7 (14), PT9 (1) & $14.3(1 / 7)$ & PT9 (1) \\
\hline \multicolumn{6}{|c|}{ AGRICULTURE COLLEGE DAIRY HERDS $(n=2)$} \\
\hline $\mathrm{D}$ & 40 & $39.5(15 / 38)$ & PT7 (15) & $50(1 / 2)$ & PT7 (1) \\
\hline $\mathrm{H}$ & 50 & $37.5(3 / 8)$ & PT7 (3) & $0(0 / 2)$ & - \\
\hline \multicolumn{6}{|c|}{ COMMUNAL ANIMAL HERDS $(n=2)$} \\
\hline M & Unknown & $0(0 / 16)$ & - & $50(1 / 2)$ & PT16 (1) \\
\hline
\end{tabular}

${ }^{*}$ Pulsotypes common to both bovine and human S. aureus are shown in bold.

$1), \operatorname{selr}(n=3), \operatorname{selu}(n=2)$, and tsst-1 $(n=2)$. None of the bovine or human $S$. aureus isolates tested positive for the seb, sed, see, seh, or selp genes. The immune evasion cluster genes, chp and sak, which code the chemotaxis inhibitory protein of S. aureus (CHIPS) and the staphylokinase (SAK) enzyme, were detected in $0.7 \%(1 / 146)$ and $13 \%(19 / 146)$ of the bovine S. aureus isolates evaluated. Among the human isolates the chp and sak genes were detected in 50\% (6/12) and 66.7\% (8/12) of the isolates evaluated. None of the isolates carried the $s c n$ gene encoding the staphylococcal complement inhibitor protein (SCIN).

\section{Accessory Gene Regulator (agr) typing}

The agr of all $S$. aureus isolates could be characterized using the described agr M-PCR assay of Gilot et al. (2002). Among the isolates of bovine origin agr type I was the dominant type observed, with $93.2 \%(136 / 146)$ of the isolates found to be of this type. The remaining $6.8 \%(10 / 146)$ of the bovine isolates were agr type II. Among the $12 \mathrm{~S}$. aureus isolates recovered from the human nasal swabs, $58.3 \%$ (7/12), 16.7\% (2/12), and 25\% (3/12) were identified as agr types I, II and III respectively (Table 3 ). No $S$. aureus isolates were found to have a type IV accessory gene regulator.

\section{Genomic Macrorestriction and Pulsed-Field Gel Electrophoresis}

All S. aureus isolates could be typed using macrorestriction followed by PFGE. Digestion of genomic DNA with SmaI produced eight to 13 fragments which ranged in size from $<76$ $\mathrm{kb}$ to approximately $674 \mathrm{~kb}$. The $S$. aureus isolates of bovine origin generated 58 electrophoretic patterns which grouped into
10 pulsotypes (PT1 to PT10) at an 80\% similarity level (Figure 2). The majority of the bovine isolates, 93.2\% (136/146), grouped into four major pulsotypes [PT1 $(n=21,14.4 \%)$, PT2 $(n=36$, 24.7\%), PT7 $(n=69,47.3 \%)$, and PT10 $(n=10,6.8 \%)]$. At five of the sampling sites (A, C, D, E, and $\mathrm{H}$ ) only a single $S$. aureus pulsotype was recovered from the mastitic milk samples. Two S. aureus pulsotypes were identified at sites B and F, whilst four pulsotypes were identified amongst the isolates from site $G$ and five $S$. aureus pulsotypes were identified at site I. Three $S$. aureus isolates (E/CPS1h; D/CPS16h; and L/CPS1h) recovered from human nasal swabs were assigned to pulsotypes common to bovine isolates namely PT2, PT7, and PT9. The nine remaining human isolates were allocated to seven separate pulsotypes (PT11-PT17).

\section{Genotyping of Staphylococcus aureus Isolates}

The 16 representative $S$. aureus isolates of bovine origin were assigned to 11 different spa types which varied in length between 1 and 11 repeats. Four new spa types, t15533 $(n=1)$, t15536 $(n=1), \operatorname{t15538}(n=1)$ and $\mathrm{t} 15539(n=4)$ were identified among the bovine isolates in this study. Other spa types detected include: $\mathrm{t} 015(n=1), \mathrm{t} 064(n=1), \mathrm{t} 189(n=1), \mathrm{t} 529(n=$ $1)$, t693 $(n=1), \mathrm{t} 730(n=1)$, and t1201 $(n=3)$. Among the ten representative human $S$. aureus isolates a diverse range of spa types were detected including: t012 $(n=1), \mathrm{t} 015(n=1)$, t064 $(n=1), \mathrm{t} 189(n=1), \mathrm{t} 360(n=1), \mathrm{t} 581(n=1), \mathrm{t} 1201(n$ $=1), \mathrm{t} 1476(n=1), \mathrm{t} 2172(n=1)$, and t7023 $(n=1)$. MLST of isolates revealed a limited number of predominant sequence types among the 16 bovine isolates typed with ST352 (CC97) ( $n$ 


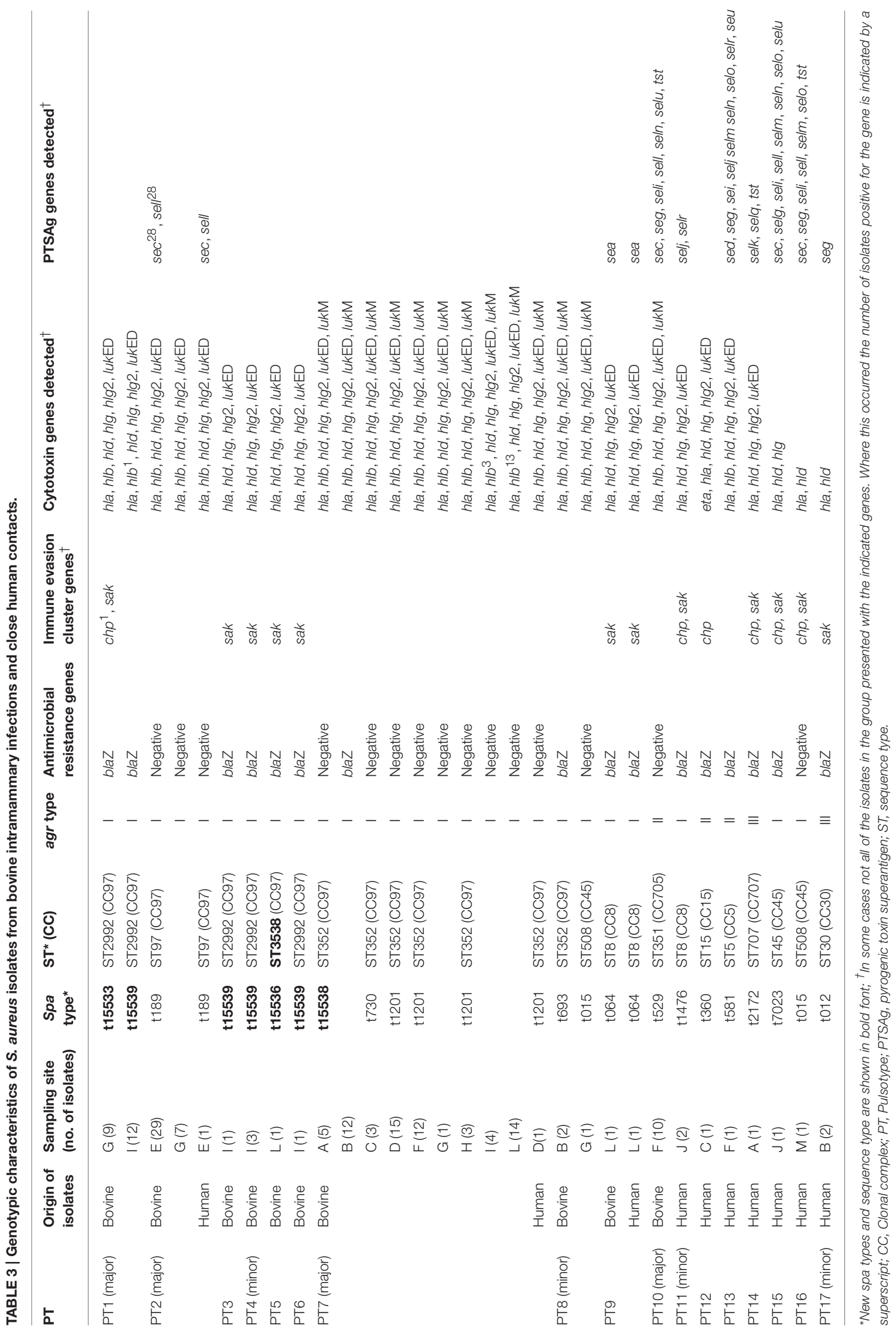




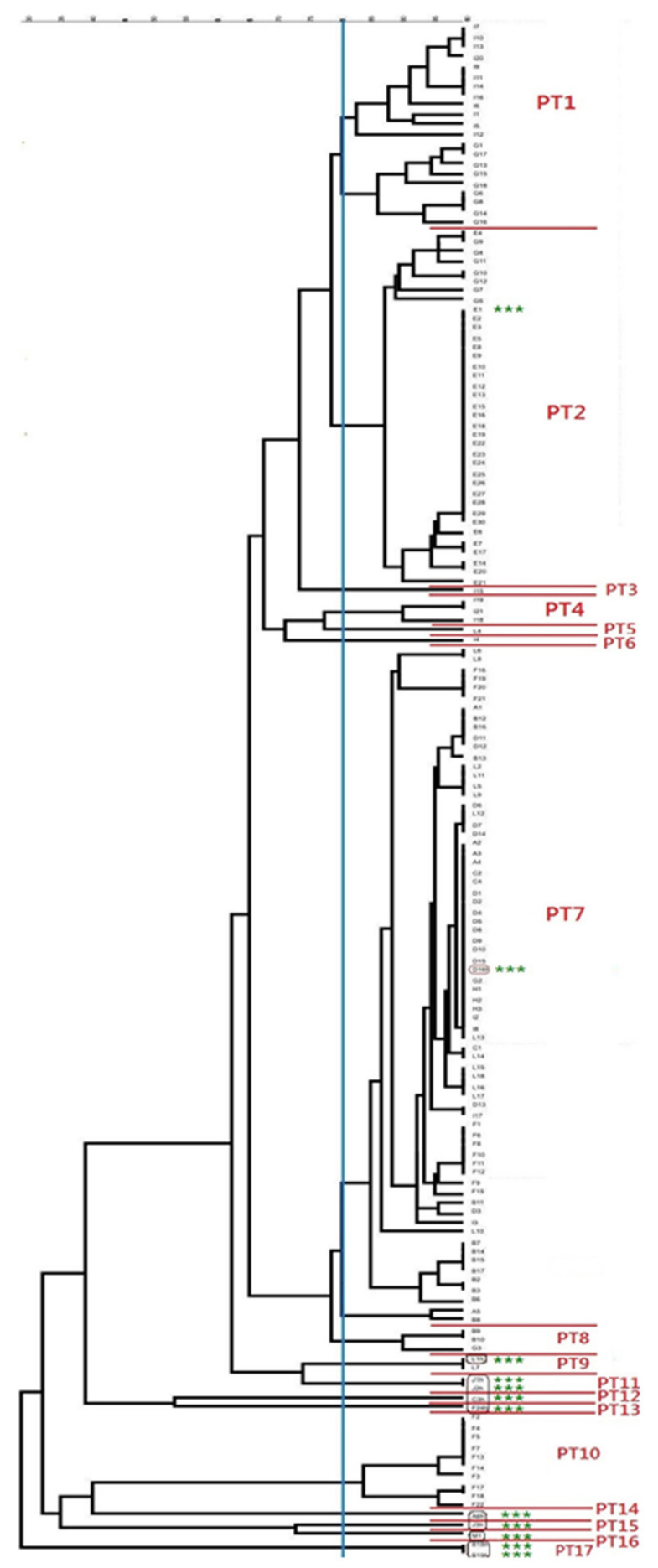

FIGURE 2 | Dendrogram showing the genetic relatedness of bovine and human Staphylococcus aureus isolates. The vertical blue line shows the $80 \%$ similarity cut-off, whilst the pulsotypes are delineated by red lines and the human isolates are highlighted using green asterisks.

$=6)$ and ST2992 (CC97) $(n=5)$ being the most common. Other sequence types detected include: ST8 (CC8) $(n=1)$, ST97 (CC97) $(n=1)$, ST351 (CC705) $(n=1)$, ST508 (CC45) $(n=1)$ and a novel sequence type, ST3538 $(n=1)$ with an allelic profile of 357-1-378-1-1-5-3. The human isolates typed as ST5 (CC5) ( $n$ $=1)$, ST8 (CC8) $(n=2)$, ST15 (CC15) $(n=1)$, ST30 (CC30) $(n=1)$, ST45 (CC45) $(n=1)$; ST97 (CC97) $(n=1)$, ST352 (CC97) $(n=1)$, ST508 (C45) $(n=1)$, and ST707 (CC707) $(n=1)$. The distribution of the different $S$. aureus sequence types and spa types are correlated with the pulsotypes in Table 3.

\section{DISCUSSION}

To investigate the specific objectives of this study a cross-section of farming operations were sampled including commercial dairy herds, government managed agriculture college herds and communal animals. The sampling approach ensured the collection of a diverse range of $S$. aureus isolates for characterization. One hundred and forty six bovine $S$. aureus isolates and 12 human isolates were characterized and genotyped using a combination of PCR and M-PCR assays, agr typing and PFGE, with representative isolates being evaluated further using spa typing and MLST.

\section{Virulence Gene Profiling of Bovine and Human Staphylococcus aureus}

Hemolysin genes were identified in all S. aureus isolates with bovine and human isolates testing positive for at least alphaand delta-hemolysin. The beta-hemolysin gene was detected in the majority $(87 \%)$ of the bovine isolates. The high occurrence of $h l b$ among bovine isolates is in agreement with other reports (Zecconi et al., 2006; Monecke et al., 2007; Ikawaty et al., 2010). Comparatively, $h l b$ was less frequently detected in human isolates. It is pertinent to relate the detection of $h l b$ to the presence of the IEC genes, which are located on $\beta$-hemolysin converting bacteriophages (van Wamel et al., 2006), as the occurrence of IEC genes is accompanied by insertional inactivation of $h l b$. The IEC genes are considered a hallmark of human S. aureus isolates, although it has been demonstrated that not all human isolates carry these genes (Verkaik et al., 2011). In this study sak was detected in $67 \%(8 / 12)$ of the human isolates examined. This is not particularly high but may simply be a consequence of the limited number of human isolates evaluated in this study. Comparatively, sak was only sporadically detected among the bovine mastitis isolates in this study with 13\% (19/146) of isolates found to carry the gene. With the exception of one of the 19 isolates, the $h l b$ gene was not detected in any of the sak-positive bovine isolates.

All bovine isolates evaluated were positive for $l u k \mathrm{ED}$, this is consistent with the results of other studies which have reported a high prevalence of $l u k E D$ among bovine mastitis isolates (Fueyo et al., 2005; Monecke et al., 2007). Interesting to note was the distribution of lukM which was predominantly detected among isolates from two of the major bovine pulsotypes namely PT7 and PT10. Rainard et al. (2003) demonstrated that $l u k \mathrm{M}$ was highly cytotoxic for bovine neutrophils leading the researchers to conclude that isolates producing this toxin would have a selective advantage in the bovine host enabling the bacteria to overcome the host immune system and establish infection 
(Rainard et al., 2003; Hata et al., 2006, 2010; Vrieling et al., 2015). This observation has been verified in vivo where Haveri et al. (2007) found lukM-positive S. aureus strains more likely to be associated with clinical mastitis cases instead of subclinical infections.

All S. aureus isolates were screened for a comprehensive range of PTSAg genes including the genes encoding the classical enterotoxins, enterotoxin A [SEA] to enterotoxin E [SEE], the newer enterotoxins [SEG, SEH, SEI], enterotoxin-like proteins [SElJ, SElK, SElL, SElM, SElN, SElO, SElP, SElQ SElR, SElU] and the toxic shock syndrome toxin-1 [TSST-1]. Although approximately $27 \%$ of the bovine $S$. aureus isolates in this study tested positive for one or more PTSAg genes, all of these isolates originated from only three herds namely, E, F, and L. The secsell gene combination was detected in the majority of the bovine isolates originating from herd $\mathrm{E}$ whilst in herd $\mathrm{F}$ the sec and sell genes presented together with seg, seli, seln, selu, and tst. Many of the genes encoding PTSAgs reside on mobile genetic elements, which accounts for the co-occurrence of particular genes as well as the horizontal dissemination of genes amongst compatible bacterial strains residing in the same ecological niche. The sec and sell genes have been shown to reside on the pathogenicity island SaPI3 (Fitzgerald et al., 2001; Holtfreter and Broeker, 2005) whilst the combination of sec-sell together with tst is characteristic of SaPI2 (Fitzgerald et al., 2001; Smyth et al., 2005). Enterotoxin C is recognized as an important virulence factor in bovine mastitis and SEC-producing $S$. aureus strains have been associated with cases of severe mastitis (Matsunaga et al., 1993; Ferens et al., 1998; Haveri et al., 2007).

The carriage of PTSAgs by S. aureus isolates recovered from cases of bovine mastitis has varied considerably between studies (Srinivasan et al., 2006; Haveri et al., 2007; Wang et al., 2009; de Freitas Guimarães et al., 2013). In addition to S. aureus strain variation, which may be influenced by environmental and management factors, the observed differences could also be attributable to herd selection criteria or the geographic location of the study (Srinivasan et al., 2006). One study conducted in the United States reported the occurrence of one or more PTSAgs in more than 93\% of the S. aureus isolates investigated (Srinivasan et al., 2006). The high prevalence led the investigators to suggest that PTSAgs are important in the development and, or, maintenance of intramammary infections. Given the immunosuppressive effect PTSAgs have on the host's immune system it is certainly a reasonable conclusion. In general data from other studies have reported much lower PTSAg gene prevalences with figures ranging from 10 to $70 \%$ (Haveri et al., 2007; Oliveira et al., 2011; de Freitas Guimarães et al., 2013). Overall the wide range in prevalences suggest that PTSAgs may provide $S$. aureus strains with a competitive advantage but these toxins are not essential for the development of mastitis (Wang et al., 2009; de Freitas Guimarães et al., 2013). It is apparent that the exact role of each toxin in the pathogenesis of staphylococcal mastitis still requires clarification.

The low occurrence of PTSAgs detected among the bovine $S$. aureus isolates evaluated in this study should also be considered in terms of the public health impact. The milk from sub-clinical cases of mastitis will enter into the milk supply chain together with PTSAg-positive $S$. aureus strains. The risk of bacterial transfer to workers in the supply chain or the ingestion of raw or incorrectly pasteurized milk is likely to be minimal in light of the low prevalence of PTSAg gene-positive $S$. aureus detected in this study.

\section{Diversity of Bovine Isolates within Herds and Relation to Global Clonal Lineages}

The number of $S$. aureus pulsotypes causing IMIs in the dairy herds investigated ranged from one to five, with one $(n=5)$ or two $(n=2)$ pulsotypes being detected in the majority of herds. The most common pulsotype PT7, was detected in 75\% (9/12) of the herds sampled. The limited genetic diversity observed within herds is consistent with the clonal nature of $S$. aureus and the contagious, lateral spread of the bacterium between cows in close contact (Capurro et al., 2010). The S. aureus isolates recovered from two herds, G and I, comprised of four and five $S$. aureus pulsotypes respectively. The owner of herd G indicated that cows and replacement heifers were sourced from other herds, in addition to rearing his own calves. This practice could account for the larger number of $S$. aureus pulsotypes observed amongst the mastitis isolates recovered from this herd. Middleton et al. (2002) reported that herds that used replacement heifers had more strains of $S$. aureus than closed herds which supplemented their dairy herds with their own stock. The same reason cannot be used to explain the high number of $S$. aureus pulsotypes detected in Herd I as the owner reportedly maintains a closed herd and rears his own replacement heifers. Other factors which are believed to influence genetic diversity and which may be contributing factors in this herd, include, herd size, milk parlor practices and specific management practices including treatment protocols and policies regarding the segregation and, or, the culling of $S$. aureus positive cows (Middleton et al., 2002; Middleton, 2013).

MLST of isolates belonging to the predominant bovine pulsotype PT7, and the second major pulsotype, PT2, identified the strains as ST352 (CC97) and ST97 (CC97) respectively. Both sequence types have been reported extensively from bovine mastitis cases in many countries including, but not limited to, Brazil, Chile, Italy, Japan, Norway, Spain, the Netherlands and the United States (Smith et al., 2005; Rabello et al., 2007; Hata et al., 2010). The expansive distribution of this successful lineage suggests that the strains are specifically adapted to the bovine host (Smith et al., 2005; Budd et al., 2015).

MLST of representative isolates from PT1, PT3, PT4, and PT6 were found to have a sequence type corresponding to $S$. aureus ST2992. Interestingly only a single report on the occurrence of S. aureus ST2992, a single-locus variant (SLV) of ST97, could be found in the literature. This ST was previously reported as a carriage isolate from a moose in a Polish study (http://saureus.mlst.net). All ST2992 isolates in this study presented with novel spa types. A novel $S$. aureus sequence type, ST3538, was identified from a milk sample collected at sampling site L. The sequence type, which also presented with a novel spa type, is a SLV of ST2992 (CC97). The detection of a new S. aureus 
sequence type is further evidence supporting the diversification of CC97.

The S. aureus isolates comprising PT10 originated from a single herd, sampling site F, and were genotyped as ST351 (CC705). This cluster of isolates is interesting for a number of reasons. Firstly, these isolates were the only bovine $S$. aureus isolates found to have a type II accessory gene regulator. All other bovine $S$. aureus isolates in this study were found to have a type I accessory gene regulator; a finding which is consistent with other reports (Gilot and van Leeuwen, 2004; Buzzola et al., 2007). It has been demonstrated that $S$. aureus strains belonging to agr group I can invade epithelial cells and persist in higher numbers in mammary gland tissue than strains belonging to other agr groups (Buzzola et al., 2007), suggesting a functional adaptation to the udder milieu. The second point of interest regarding PT10/ST351 isolates is that all 10 isolates tested negative using a commercial slide agglutination test which is used for the rapid identification of $S$. aureus isolates. Stutz et al. (2011) reported a similar observation with bovine mastitis isolates when using a different commercial kit which was based on the same biological principles. The researchers attributed the negative results to genetic polymorphisms in the clumping factor (clfA) and fibronectin-binding ( $f n b \mathrm{~A})$ genes as well as a premature stop codon in the spa gene. Subsequent genotyping of the isolates by Moser et al. (2013) found all isolates to be ST151 (CC151). Staphylococcus aureus ST351 is a double locus variant of ST151 and it would be interesting to establish if the molecular basis behind the agglutination-negative result is due to similar genetic polymorphisms. The practical implication of the falsenegative test results reported with the latex agglutination test kit is quite considerable, especially in mastitis diagnostic laboratories relying on the assay to identify presumptive $S$. aureus isolates (Pyörälä et al., 2011; Stutz et al., 2011).

\section{Genotypic Relatedness of Bovine and Human Staphylococcus aureus Isolates and Investigation of Transmission between Hosts}

From the 13 sampling sites, S. aureus was simultaneously recovered from bovine milk and human nasal swabs at seven of the sites. The diversity and genetic relatedness of the bovine and human $S$. aureus isolates were initially examined through the use of PFGE. In comparison to the bovine isolates, the $S$. aureus strains recovered from close human contacts were far more genetically diverse. Nine of the 12 human isolates clustered separately from the bovine isolates in eight separate pulsotypes (PT11 to PT17) and comprised of multilocus sequence types not evident among the bovine isolates including ST5, ST15, ST30, ST45, and ST707.

At three of the sampling sites, D, E, and L, the S. aureus isolates recovered from both of the hosts were genetically indistinguishable. At sites $\mathrm{D}$ and $\mathrm{E}$, the predominant bovine strains detected, PT7/ST352/CC97/t1201 and PT2/ST97/CC97/t189 respectively were also recovered from human nasal swabs collected at the sites. Staphylococcus aureus ST97 strains have been reported from human carriage and clinical specimens (Lozano et al., 2011; Udo et al., 2011; Spoor et al., 2013). The presence of virulence markers such as $h l b$, lukED, and $l u k \mathrm{M}$, which, although not exclusively found in bovine-associated strains, but are known to provide a selective advantage in the bovine host, suggest that the $S$. aureus isolates are bovine in origin. So does the lack of IEC-associated genes. Unfortunately, due to the fact that only a single round of sampling was done it was not possible to establish in the above cases whether the human contacts were transiently or permanently colonized with this $S$. aureus strain.

At sampling site L, genetically indistinguishable $S$. aureus strains belonging to PT9/ST8/CC8/t064 were recovered from both milk and human nasal swabs. The majority of the bovine isolates collected from this site were ST352; no other S. aureus ST8 isolates were detected. Staphylococcus aureus ST8 has been reported extensively from human carriage and clinical specimens (Sakwinska et al., 2009; Oosthuysen et al., 2014). This lineage also comprises a number of significant MRSA clones (Monecke et al., 2011). Whilst ST8 has been documented from cases of bovine mastitis (Sakwinska et al., 2011) the prevailing context in this herd, suggests the $S$. aureus isolate is of human origin and has been transferred to the bovine host.

The close contact between dairy cows and humans, particularly in the milking parlor creates the opportunity for the transmission of bacteria between hosts. Whilst evidence suggests that some $S$. aureus strains are adapted to colonize and infect certain host species, other lineages are non-specific. Irrespective hereof, $S$. aureus is a versatile pathogen and is readily able to adapt to new environments through gene mutation, transfer and decay (Spoor et al., 2013). It is primarily for this reason that the interface between animal populations and humans needs to be monitored in order to allow for changes in population dynamics to be timeously detected.

The low number of human $S$. aureus isolates recovered from the nasal swabs of close human contacts is considered one of the primary limitations of this study. The availability of only 12 human $S$. aureus isolates restricted the comparisons which could be made between isolates originating from bovine and human hosts. Further sampling at additional sites in KZN and other provinces of South Africa will potentially provide a larger number of isolates for characterization and will enable the preliminary observations made in this study to be confirmed.

\section{CONCLUSION}

This study presents the first insight into the virulence characteristics and genetic diversity of $S$. aureus strains causing mastitis in dairy herds in a province of South Africa. The absence of clinically significant antimicrobial resistance genes and virulence markers, such as the Panton Valentine leukocidin encoding gene $(p v l)$, together with the low occurrence of PTSAg genes among bovine isolates suggests that the human and public health risks posed by the bovine $S$. aureus populations are low. Genotyping of bovine isolates revealed a limited number of clones with several new spa types and a new $S$. aureus sequence type being documented. A greater genetic diversity was observed 
among the human isolates evaluated in this study. The detection of genotypically indistinguishable $S$. aureus isolates from bovine and human hosts at three of the sampling sites is suggestive of bacterial transmission and supports the need for vigilant monitoring of $S$. aureus populations at the interface between dairy cows and humans.

\section{AUTHOR CONTRIBUTIONS}

TS, ME, and MK conceived and designed the study. TS collected samples and performed all laboratory analyses. TS and MK analyzed the genotyping data. TS wrote the manuscript with critical appraisal and contributions received from all of the authors. All authors read and approved the final version of the manuscript.

\section{REFERENCES}

Akineden, Ö., Annemüller, C., Hassman, A. A., Lämmler, C., Wolter, W., and Zschöck, M. (2001). Toxin genes and other characteristics of Staphylococcus aureus isolates from milk of cows with mastitis. Clin. Diag. Lab. Immunol. 8, 959-964. doi: 10.1128/cdli.8.5.959-964.2001

Argudín, M. Á., Mendoza, M. C., and Rodicio, M. R. (2010). Food poisoning and Staphylococcus aureus enterotoxins. Toxins 2, 1751-1773. doi: 10.3390/toxins 2071751

Becker, K., Skov, R. L., and von Eiff, C. (2015). "Staphylococcus, Micrococcus, and other catalase-positive cocci," in Manual of Clinical Microbiology, 11th Edn, eds J. H. Jorgensen, M. A. Pfaller, K. C. Carroll, G. Funke, M. L. Landry, S. S. Richter, et al. (Washington, DC: ASM Press), 354-382.

Ben Ayed, S., Boutiba-Ben Boubaker, I., Ennigrou, S., and Ben Redjeb, S. (2008). Accessory gene regulator (agr) typing of Staphylococcus aureus isolated from human infections. Archs. Inst. Pasteur Tunis 85, 1-4.

Budd, K. E., McCoy, F., Monecke, S., Cormica, P., Mitchell, J., and Keane, O. M. (2015). Extensive genomic diversity among bovine-adapted Staphylococcus aureus: evidence for a genomic rearrangement within CC97. PLoS ONE 10:e0134592. doi: 10.1371/journal.pone.0134592

Buzzola, F. R., Alvarez, L. P., Tuchscherr, L. P. N., Barbagelata, M. S., Lattar, S. M., Calvinho, L., et al. (2007). Differential abilities of capsulated and noncapsulated Staphylococcus aureus isolates from diverse agr groups to invade mammary epithelial cells. Infect. Immun. 75, 886-891. doi: 10.1128/IAI.01215-06

Capurro, A., Aspán, A., Ericsson Unnerstad, H., Persson Waller, K., and Artursson, K. (2010). Identification of potential sources of Staphylococcus aureus in herds with mastitis problems. J. Dairy Sci. 93, 180-191. doi: 10.3168/jds.2009-2471

Clark, N. C., Cooksey, R. C., Hill, B. C., Swenson, J. M., and Tenover, F. C. (1993). Characterization of glycopeptide-resistant enterococci from U.S. hospitals. Antimicrob. Agents Chemother. 37, 2311-2317. doi: 10.1128/AAC.37.11.2311

Cuny, C., Wieler, L. H., and Witte, W. (2015). Livestock-associated MRSA: the impact on humans. Antibiotics 4, 521-543. doi: 10.3390/antibiotics4040521

de Freitas Guimarães, F., Nóbrega, D. B., Bodelão Richini-Pereira, V. B., Marson, P. M., de Figueiredo, J. C. P., Langoni, P., et al. (2013). Enterotoxin genes in coagulase-negative and coagulase-positive staphylococci isolated from bovine milk. J. Dairy Sci. 96, 1-7. doi: 10.3168/jds.2012-5864

Enright, M. C., Day, N. P., Davies, C. E., Peacock, S. J., and Spratt, B. G. (2000). Multilocus sequence typing for characterization of methicillin-resistant and methicillin-susceptible clones of Staphylococcus aureus. J. Clin. Microbiol. 38, 1008-1015.

Faria, N. A., Carrico, J. A., Oliveira, D. C., Ramirez, M., and de Lencastre, H. (2008). Analysis of typing methods for epidemiological surveillance of both methicillin-resistant and methicillin-susceptible Staphylococcus aureus strains. J. Clin. Microbiol. 46, 136-144. doi: 10.1128/JCM.01684-07

Feil, E., Cooper, J., Grundmann, H., Robinson, D., Enright, M., Berendt, T., et al. (2003). How clonal is Staphylococcus aureus? J. Bacteriol. 185, 3307-3316. doi: 10.1128/JB.185.11.3307-3316.2003

\section{FUNDING}

The authors would like to thank the University of Pretoria, National Health Laboratory Services, RESCOM, the National Research Foundation (NRF) Research Technology Fund (RTF14011560804) and the KZN Department of Agriculture and Rural Development for financial support.

\section{ACKNOWLEDGMENTS}

The authors wish to thank Dr. S Monecke (Institute for Medical Microbiology and Hygiene, TU Dresden, Germany) for his kind contribution of characterized $S$. aureus field isolates which were used as controls in this study. Ms Vigie Govender is thanked for her assistance in generating the map used in this article.

Ferens, W. A., Davis, W. C., Hamilton, M. J., Park, Y. H., Deobald, C. F., Fox, L., et al. (1998). Activation of bovine lymphocyte subpopulations by staphylococcal enterotoxin C. Infect. Immun. 66, 573-580.

Ferry, T., Perpoint, T., Vandenesch, F., and Etienne, J. (2005). Virulence determinants in Staphylococcus aureus and their involvement in clinical syndromes. Curr. Infect. Dis. Rep. 7, 420-428. doi: 10.1007/s11908-0050043-8

Feßler, A., Scott, C., Kadlec, K., Ehricht, R., Monecke, S., and Schwarz, S. (2010). Characterization of methicillin-resistant Staphylococcus aureus ST398 from cases of bovine mastitis. J. Antimicrob. Chemoth. 65, 619-625. doi: $10.1093 / \mathrm{jac} / \mathrm{dkq} 021$

Fitzgerald, J. R. (2012). Livestock-associated Staphylococcus aureus: origin, evolution and public health threat. Trends Microbiol. 20, 192-198. doi: 10.1016/j.tim.2012.01.006

Fitzgerald, J. R., Sturdevant, D. E., Mackie, S. M., Gill, S. R., and Musser, J. M. (2001). Evolutionary genomics of Staphylococcus aureus: insights into the origin of methicillin-resistant strains and the toxic shock syndrome epidemic. Proc. Natl. Acad. Sci. U.S.A. 98, 8821-8826. doi: 10.1073/pnas.161098098

Fueyo, J. M., Mendoza, M. C., Rodicio, M. R., Muñiz, J., Alvarez, M. A., and Martín, M. C. (2005). Cytotoxin and pyrogenic toxin superantigen gene profiles of Staphylococcus aureus associated with subclinical mastitis in dairy cows and relationships with macrorestriction genomic profiles. J. Clin. Microbiol. 43, 1278-1284. doi: 10.1128/jcm.43.3.1278-1284.2005

Gilot, P., Lina, G., Cochard, T., and Poutrel, B. (2002). Analysis of the genetic variability of genes encoding the RNA III-activating components Agr and TRAP in a population of Staphylococcus aureus strains isolated from cows with mastitis. J. Clin. Microbiol. 40, 4060-4067. doi: 10.1128/JCM.40.11.4060-4067.2002

Gilot, P., and van Leeuwen, W. (2004). Comparative analysis of agr locus diversification and overall genetic variability among bovine and human Staphylococcus aureus isolates. J. Clin. Microbiol. 42, 1265-1269. doi: 10.1128/JCM.42.3.1265-1269.2004

Gordon, R., and Lowy, F. C. (2008). Pathogenesis of methicillinresistant Staphylococcus aureus infection. Clin. Infect. Dis. 46, 350-359. doi: $10.1086 / 533591$

Graveland, H., Duim, B., van Duijkeren, E., Heederik, D., and Wagenaar, J. A. (2011). Livestock-associated methicillin-resistant Staphylococcus aureus in animals and humans. Int. J. Med. Microbiol. 301, 630-634. doi: 10.1016/j.ijmm.2011.09.004

Graves, L. M., and Swaminathan, B. (2001). PulseNet standardized protocol for subtyping Listeria monocytogenes by macrorestriction and pulsed-field gel electrophoresis. Int. J. Food Microbiol. 65, 55-62. doi: 10.1016/S0168-1605(00)00501-8

Haenni, M., Galofaro, L., Ponsin, C., Bes, M., Laurent, F., and Madec, J. Y. (2010). Staphylococcal bovine mastitis in France: enterotoxins, resistance and the human Geraldine methicillin-resistant Staphylococcus aureus clone. J. Antimicrob. Chemother 66, 216-218. doi: 10.1093/jac/dkq417 
Harmsen, D., Claus, H., Witte, W., Rothgänger, J., Claus, H., Turnwald, D., et al. (2003). Typing of methicillin-resistant Staphylococcus aureus in a university hospital setting by using novel software for spa repeat determination and database management. J. Clin. Microbiol. 41, 5442-5448. doi: 10.1128/JCM.41.12.5442-5448.2003

Hata, E., Katsuda, K., Kobayashi, H., Nishimori, K., Uchida, I., Higashide, M., et al. (2008). Bacteriological characteristics of Staphylococcus aureus isolates from humans and bulk milk. J. Dairy Sci. 91, 564-569. doi: 10.3168/jds.2007-0457

Hata, E., Katsuda, K., Kobayashi, H., Ogawa, T., Endo, T., and Eguchi, M. (2006). Characteristics and epidemiologic genotyping of Staphylococcus aureus isolates from bovine mastitic milk in Hoddaido, Japan. J. Vet. Med. Sci. 68, 165-170. doi: 10.1292/jvms.68.165

Hata, E., Katsuda, K., Kobayashi, H., Uchida, I., Tanaka, K., and Eguchi, M. (2010). Genetic variation among Staphylococcus aureus strains from bovine milk and their relevance to methicillin-resistant isolates from humans. J. Clin. Microbiol. 48, 2130-2139. doi: 10.1128/JCM.01940-09

Haveri, M., Hovinen, M., Roslöf, A., and Pyörälä, S. (2008). Molecular types and genetic profiles of Staphylococcus aureus strains isolated from bovine intramammary infections and extramammary sites. J. Clin. Microbiol. 46, 3728-3735. doi: 10.1128/JCM.00769-08

Haveri, M., Roslöf, A., Rantala, L., and Pyörälä, S. (2007). Virulence genes of bovine Staphylococcus aureus from persistent and nonpersistent intramammary infections with different clinical characteristics. J. App. Microbiol. 103, 993-1000. doi: 10.1111/j.1365-2672.2007.03356.x

Haveri, M., Taponen, S., Vuopio-Varkila, J., Salmenlinna, S., and Pyörälä, S. (2005). Bacterial genotype affects the manifestation and persistence of bovine Staphylococcus aureus intramammary infection. J. Clin. Microbiol. 43, 959-961. doi: 10.1128/JCM.43.2.959-961.2005

Holtfreter, S., and Broeker, B. M. (2005). Staphylococcal superantigens: do they play a role in sepsis? Arch. Immunol. Ther. Exp. 53, 13-27.

Ikawaty, R., Brouwer, E. C., van Duijkeren, E., Mevius, D., Verhoef, J., and Fluit, A. C. (2010). Virulence factors of genotyped bovine mastitis Staphylococcus aureus isolates in the Netherlands. Int. J. Dairy Sci. 5, 60-70. doi: $10.3923 /$ ijds.2010.60.70

Jarraud, S., Mougel, C., Thioulouse, J., Lina, G., Meugnier, H., Forey, F., et al. (2002). Relationships between Staphylococcus aureus genetic background, virulence factors, agr groups (alleles), and human disease. Infect. Immun. 70, 631-641. doi: 10.1128/IAI.70.2.631-641.2002

Joo, Y. S., Fox, L. K., Davis, W. C., Bohach, G. A., and Park, Y. H. (2001). Staphylococcus aureus associated with mammary glands of cows: genotyping to distinguish different strains among herds. Vet. Microbiol. 80, 131-138. doi: 10.1016/S0378-1135(00)00381-3

Juhász-Kaszanyitzky, É., Jánosi, S., Somogyi, P., Dán, Á., van der Graaf-van Bloois, L., van Duijkeren, E., et al. (2007). MRSA transmission between cows and humans. Emerg. Infect. Dis. 13, 630-632. doi: 10.3201/eid1304. 060833

Kadlec, K., Wendlandt, S., Feßler, A. T., and Schwarz, S. (2015). "Methods for the detection of antimicrobial resistance and the characterization of Staphylococcus aureus isolates from food-producing animals and food of animal origin," in Antimicrobial Resistance and Food Safety, eds C.-Y. Chen, X. Yan, and C. R. Jackson (Chennai: Academic Press), 207-232.

Kapur, V., Sischo, W., Greer, R., Whittam, T., and Musser, J. (1995). Molecular population genetic analysis of Staphylococcus aureus recovered from cow. J. Clin. Microbiol. 33, 376-380.

Le Loir, Y., Baron, F., and Gautier, M. (2003). Staphylococcus aureus and food poisoning. Gen. Mol. Res. 2, 63-76.

Lindsay, J. A., and Holden, M. T. (2004). Staphylococcus aureus: superbug, super genome? Trends Microbiol. 12, 378-385. doi: 10.1016/j.tim.2004.06.004

Lowy, F. (2013). "Staphylococcal infections," in Harrison's Principles of Internal Medicine, eds A. Fauci, E. Braunwald, D. Casper, S. Hauser, D. Longo, J. Jameson, et al. (New York, NY: The McGraw-Hill Companies Inc.), 386-399.

Lozano, C., Gómez-Sanz, E., Benito, D., Aspiroz, C., Zarazaga, M., and Torres, C. (2011). Staphylococcus aureus nasal carriage, virulence traits, antibiotic resistance mechanisms, and genetic lineages in healthy humans in Spain, with detection of CC398 and CC97 strains. Int. J. Med. Microbiol. 301, 500-505. doi: 10.1016/j.ijmm.2011.02.004

Lundberg, Å., Aspán, A., Nyman, A., Ericsson Unnerstad, H., and Persson Waller, K. (2014). Associations between bacterial genotype and outcome of bovine clinical Staphylococcus aureus mastitis. Acta Vet. Scand. 56:2. doi: 10.1186/1751-0147-56-2

Matsunaga, T., Kamata, S., Kakiichi, N., and Uchida, K. (1993). Characteristics of Staphylococcus aureus isolated from peracute, acute and chronic bovine mastitis. J. Vet. Med. Sci. 55, 297-300. doi: 10.1292/jvms.55.297

McClure, J.-A., Conly, J. M., Lau, V., Elsayed, S., Louie, T., Hutchins, W., et al. (2006). Novel multiplex PCR assay for detection of Staphylococcal virulence marker Panton-Valentine leukocidin genes and simultaneous discrimination of methicillin-susceptible from -resistant staphylococci. J. Clin. Microbiol. 44, 1141-1144. doi: 10.1128/JCM.44.3.1141-1144.2006

McDougal, L. K., Steward, C. D., Killgore, G. E., Chaitram, J. M., McAllister, S. K., and Tenover, F. C. (2003). Pulsed-field gel electrophoresis typing of oxacillin-resistant Staphylococcus aureus isolates from the United States: establishing a national database. J. Clin. Microbiol. 41, 5113-5120. doi: 10.1128/JCM.41.11.5113-5120.2003

Mehrotra, M., Wang, G., and Johnson, W. M. (2000). Multiplex PCR for detection of genes for Staphylococcus aureus enterotoxins, exfoliative toxins, toxic shock syndrome toxin 1, and methicillin resistance. J. Clin. Microbiol. 38, 1032-1035.

Middleton, J. R. (2013). "Staphylococcus aureus: have we learned anything in the last 50 years?" in Proceedings of the National Mastitis Council (NMC) Regional Meeting 2013. Available online at: http://www.nmconline.org/articles/staphaureus50.pdf [Accessed 8 July 2016].

Middleton, J. R., Fox, L. K., Gay, J. M., Tyler, J. W., and Besser, T. E. (2002). Use of pulsed-field gel electrophoresis for detecting differences in Staphylococcus aureus strain populations between dairy herds with different cattle importation practices. Epidemiol. Infect. 129, 387-395. doi: 10.1017/S09502688020 0746X

Monecke, S., Coombs, G., Shore, A. C., Coleman, D. C., Akpaka, P., Borg, M., et al. (2011). A field guide to pandemic, epidemic and sporadic clones of methicillin-resistant Staphylococcus aureus. PLoS ONE 6:e17936. doi: 10.1371/journal.pone.0017936

Monecke, S., Kuhnert, P., Hotzel, H., Slickers, P., and Ehricht, R. (2007). Microarray based study on virulence-associated genes and resistance determinants of Staphylococcus aureus isolates from cattle. Vet. Microbiol. 125, 128-140. doi: 10.1016/j.vetmic.2007.05.016

Moser, A., Stephan, R., Corti, S., and Johler, S. (2013). Comparison of genomic and antimicrobial resistance features of latex agglutination test-positive and latex agglutination test-negative Staphylococcus aureus isolates causing bovine mastitis. J. Dairy Sci. 96, 329-334. doi: 10.3168/jds.2012-5944

Oliveira, L., Rodrigues, A. C., Hulland, C., and Ruegg, P. L. (2011). Enterotoxin production, enterotoxin gene distribution, and genetic diversity of Staphylococcus aureus recovered from milk of cows with subclinical mastitis. Am. J. Vet. Microbiol. 72, 1361-1368. doi: 10.2460/ajvr.72.10.1361

Omoe, K., Hu, D.L., Takahashi-Omoe, H., Nakane, A., and Shinagawa, K. (2005). Comprehensive analysis of classical and newly described staphylococcal superantigenic toxin genes in Staphylococcus aureus isolates. FEMS Microbiol. Lett. 246, 191-198. doi: 10.1016/j.femsle.2005.04.007

Omoe, K., Ishikawa, M., Shimoda, Y., Hu, D.-L., Ueda, S., and Shinagawa, K. (2002). Detection of seg, seh, and sei genes in Staphylococcus aureus isolates and determination of the enterotoxin productivities of $S$. aureus isolates harbouring seg, seh, or sei genes. J. Clin. Microbiol. 40, 857-862. doi: 10.1128/JCM.40.3.857-862.2002

Oosthuysen, W. F., Orth, H., Lombard, C. J., Sinha, B., and Wasserman, E. (2014). Population structure analyses of Staphylococcus aureus at Tygerberg hospital, South Africa, reveals a diverse population, a high prevalence of PantonValentine leukocidin genes, and unique local methicillin-resistant $S$. aureus clones. Clin. Microbiol. Infect. 20, 652-659. doi: 10.1111/1469-0691.12452

Park, J.Y., Fox, L. K., Seo, K. S., McGuire, M. A., Park, Y. H., Rurangirwa, F. R., et al. (2011). Detection of classical and newly described staphylococcal superantigen genes in coagulase-negative staphylococci isolated from bovine intramammary infections. Vet. Microbiol. 147, 149-154. doi: 10.1016/j.vetmic.2010.06.021

Petrovski, K. R., Trajcev, M., and Buneski, G. (2006). A review of the factors affecting the costs of bovine mastitis. J. S. Afr. Vet. Assoc. 77, 52-60. doi: 10.4102/jsava.v77i2.344

Plata, K., Rosato, A. E., and Wegrzyn, G. (2009). Staphylococcus aureus as an infectious agent: overview of biochemistry and molecular genetics of its pathogenicity. Acta Bio. Pol. 56, 597-612. 
Pyörälä, S., Simojoki, H., and Taponen, S. (2011). "News about mastitis-causing staphylococci," in Paper Presented at the European Buiatrics Forum, eds R. Maillard and H. Navetat (Marseille: Societe Francaise de Buiatrie), 93-104.

Rabello, R. F., Moreira, B. M., Lopes, R. M., Teixeira, L. M., Riley, L. W., and Castro, A. C. (2007). Multilocus sequence typing of Staphylococcus aureus isolates recovered from cows with mastitis in Brazilian dairy herds. J. Med. Microbiol. 56, 1505-1511. doi: 10.1099/jmm.0.47357-0

Rainard, P., Corrales, J. C., Barrio, M. B., Cochard, T., and Poutrel, B. (2003). Leucotoxic activities of Staphylococcus aureus strains isolated from cows, ewes, and goats with mastitis: importance of LukM/LukF'-PV leukotoxin. Clin. Diag. Lab. Immunol. 10, 272-277. doi: 10.1128/cdli.10.2.272-277.2003

Sakwinska, O., Giddey, M., Moreillon, M., Morisset, D., Waldvogen, A., and Moreillon, P. (2011). Staphylococcus aureus host range and human-bovine host shift. Appl. Environ. Microbiol. 77, 5908-5915. doi: 10.1128/AEM.00238-11

Sakwinska, O., Kuhn, G., Balmelli, C., Francioli, P., Giddey, M., Perreten, V., et al. (2009). Genetic diversity and ecological success of Staphylococcus aureus strains colonizing humans. Appl. Environ. Microbiol. 75, 175-183. doi: 10.1128/AEM.01860-08

Schmidt, T., Kock, M. M., and Ehlers, M. M. (2015). Diversity and antimicrobial susceptibility profiling of staphylococci isolated from bovine mastitis cases and close human contacts. J. Dairy Sci. 98, 6256-6269. doi: 10.3168/jds.20 15-9715

Shopsin, B., Gomez, M., Montgomery, S. O., Smith, D. H., Waddington, M., Dodge, D. E., et al. (1999). Evaluation of protein A polymorphic region DNA sequencing for typing of Staphylococcus aureus strains. J. Clin. Microbiol. 37, 3556-3563.

Smeltzer, M. S., Lee, C. Y., Harik, N., and Hart, M. E. (2009). "Molecular basis of pathogenicity," in Staphylococci in Human Disease, 2nd Edn, eds K. B. Crossley, K. Jefferson, G. L. Archer, and V. G. Fowler (Singapore: Wiley-Blackwell), 65-108.

Smith, E. M., Green, L. E., Medley, G. F., Bird, H. E., Fox, L. K., Schukken, Y. H., et al. (2005). Multilocus sequence typing of intercontinental bovine Staphylococcus aureus isolates. J. Clin. Microbiol. 43, 4737-4743. doi: 10.1128/JCM.43.9.4737-4743.2005

Smyth, D. S., Feil, E. J., Meaney, W. J., Hartigan, P. J., Tollersrud, T., Fitzgerald, J. R., et al. (2009). Molecular genetic typing reveals further insights into the diversity of animal-associated Staphylococcus aureus. J. Med. Microbiol. 58, 1343-1353. doi: 10.1099/jmm.0.009837-0

Smyth, D. S., Hartigan, P. J., Meaney, W. J., Fitzgerald, J. R., Deobald, C. F., Bohach, G. A., et al. (2005). Superantigen genes encoded by the egc cluster and SaPIbov are predominant among Staphylococcus aureus isolates from cows, goats, sheep, rabbits and poultry. J. Med. Microbiol. 54, 401-411. doi: 10.1099/jmm.0.45863-0

Sommerhäuser, J., Kloppert, B., Wolter, W., Zschöck, M., Sobiraj, A., and Failing, K. (2003). The epidemiology of Staphylococcus aureus infections from subclinical mastitis in dairy cows during a control programme. Vet. Microbiol 96, 91-102. doi: 10.1016/S0378-1135(03)00204-9

Spoor, L. E., McAdam, P. R., Weinert, L. A., Rambaut, A., Hasman, H., Aarestrup, F. M., et al. (2013). Livestock origin for a human pandemic clone of community-associated methicillin-resistant Staphylococcus aureus. mBio 4:e00356-13. doi: 10.1128/mBio.00356-13

Srinivasan, V., Sawant, A. A., Gillespie, B. E., Headrick, S. J., Ceasaris, L., and Oliver, S. P. (2006). Prevalence of enterotoxin and toxic shock syndrome toxin genes in Staphylococcus aureus isolated from milk of cows with mastitis. Foodborne Path. Dis. 3, 274-283. doi: 10.1089/fpd.2006.3.274

Stegger, M., Andersen, P. S., Kearns, A., Pichon, B., Holmes, M. A., Edwards, G., et al. (2012). Rapid detection, differentiation and typing of methicillin-resistant Staphylococcus aureus harbouring either mecA or the new mecA homologue mecA $A_{L A A 251}$. Clin. Microbiol. Infect. 18, 395-400. doi: 10.1111/j.1469-0691.2011.03715.x

Stutz, K., Stephan, R., and Tasara, T. (2011). SpA, ClfA, and FnbA genetic variations lead to Staphaurex test-negative phenotypes in bovine mastitis Staphylococcus aureus isolates. J. Clin. Microbiol. 49, 638-646. doi: 10.1128/JCM.01148-10

Sung, J. M., Lloyd, D. H., and Lindsay, J. A. (2008). Staphylococcus aureus host specificity: comparative genomics of human versus animal isolates by multi-strain microarray. Microbiology 154, 1949-1959. doi: $10.1099 /$ mic. $0.2007 / 015289-0$
Tenhagen, B. A., Vossenkuhl, B., Käsbohrer, A., Alt, K., Kraushaar, B., Guerra, B., et al. (2014). Methicillin-resistant Staphylococcus aureus in cattle food chains prevalence, diversity, and antimicrobial resistance in Germany. J. Anim. Sci. 92, 2741-2751. doi: 10.2527/jas.2014-7665

Tenover, F. C., Arbeit, R. D., Goering, R. V., Mickelsen, P. A., Murray, B. E., Persing, D. H., et al. (1995). Interpreting chromosomal DNA restriction patterns produced by pulsed-field gel electrophoresis: criteria for bacterial strain typing. J. Clin. Microbiol. 33, 2233-2239.

Trees, E., Rota, P. A., MacCannell, D., and Gerner-Smidt, P. (2015). "Molecular epidemiology," in Manual of Clinical Microbiology, 11th Edn, eds J. H. Jorgensen, M. A. Pfaller, K. C. Caroll, G. Funke, M. L. Landry, S. S. Richter et al. (Washington, DC: ASM Press), 131-160

Udo, E. E., Aly, N. Y. A., Sarkhoo, E., Al-Sawan, R., and Al-Asar, A.-S. M. (2011). Detection and characterization of an ST97-SCCmec-V communityassociated methicillin-resistant Staphylococcus aureus clone in a neonatal intensive care unit and special care baby unit. J. Med. Microbiol. 60, 600-604. doi: 10.1099/jmm.0.028381-0

van Wamel, W. J. B., Rooijakkers, S. H. M., Ruyken, M., van Kessel, K. P. M., and van Strijp, J. A. G. (2006). The innate immune modulators staphylococcal complement inhibitor and chemotaxis inhibitory protein of Staphylococcus aureus are located on $\beta$-hemolysin-converting bacteriophages. J. Bacteriol. 188, 1310-1315. doi: 10.1128/JB.188.4.1310-1315.2006

Verkaik, N. J., Benard, M., Boelens, H. A., de Vogel, C. P., Nouwen, J. L., and Verbrugh, H. A. (2011). Immune evasion cluster-positive bacteriophages are highly prevalent among human Staphylococcus aureus strains, but they are not essential in the first stages of nasal colonization. Clin. Microbial. Infect. 17, 343-348. doi: 10.1111/j.1469-0691.2010.03227.x

Vesterholm-Nielsen, M.,Olhom Larsen, M., Olsen, J. E., and Moller Aarestrup, F., (1999). Occurrence of blaZ gene in penicillin resistant Staphylococcus aureus isolated from bovine mastitis in Denmark. Acta Vet. Scand. 40, 279-286.

Vrieling, M., Koymans, K. J., Heesterbeek, D. A. C., Aerts, P. C., Rutten, V. P. M. G., de Haas, C. J., et al. (2015). Bovine Staphylococcus aureus secretes the leukocidin LukMF' to kill migrating neutrophils through CCR1. mBio 6:e00335-15. doi: 10.1128/mBio.00335-15

Wang, S.-C., Wu, C.-M., Xia, S.-C., Qi, Y.-H., Xia, L.-N., and Shen, J.-Z. (2009). Distribution of superantigenic toxin genes in Staphylococcus aureus isolates from milk samples of bovine subclinical mastitis cases in two major diary production regions of China. Vet. Microbiol. 137, 276-281. doi: 10.1016/j.vetmic.2009.01.007

Wright, J., and Novick, R. (2003). "Virulence mechanisms in MRSA pathogenesis," in MRSA: Current Perspectives, eds A. Fluit and F.-J. Schmitz (Wymondham: Caister Academic Press), 213-240.

Yamaguchi, T., Nishifuji, K., Sasaki, M., Fudaba, Y., Aepfelbacher, M., Takata, T., et al. (2002). Identification of the Staphylococcus aureus etd pathogenicity island which encodes a novel exfoliative toxin, ETD, and EDIN-B. Infect. Immun. 70, 5835-5845. doi: 10.1128/IAI.70.10.5835-5845.2002

Zadoks, R. N., van Leeuwen, W. B., Kreft, D., Fox, L. K., Barkema, H. W., Schukken, Y. H., et al. (2002). Comparison of Staphylococcus aureus isolates from bovine and human skin, milking equipment, and bovine milk by phage typing, pulsed-field gel electrophoresis, and binary typing. J. Clin. Microbiol. 40, 3894-3902. doi: 10.1128/JCM.40.11.3894-3902.2002

Zecconi, A., Cesaris, L., Liandris, E., Daprà, V., and Piccinini, R. (2006). Role of several Staphylococcus aureus virulence factors on the inflammatory response in the bovine mammary gland. Microb. Pathog. 40, 177-183. doi: 10.1016/j.micpath.2006.01.001

Conflict of Interest Statement: The authors declare that the research was conducted in the absence of any commercial or financial relationships that could be construed as a potential conflict of interest.

Copyright $\odot 2017$ Schmidt, Kock and Ehlers. This is an open-access article distributed under the terms of the Creative Commons Attribution License (CC BY). The use, distribution or reproduction in other forums is permitted, provided the original author(s) or licensor are credited and that the original publication in this journal is cited, in accordance with accepted academic practice. No use, distribution or reproduction is permitted which does not comply with these terms. 